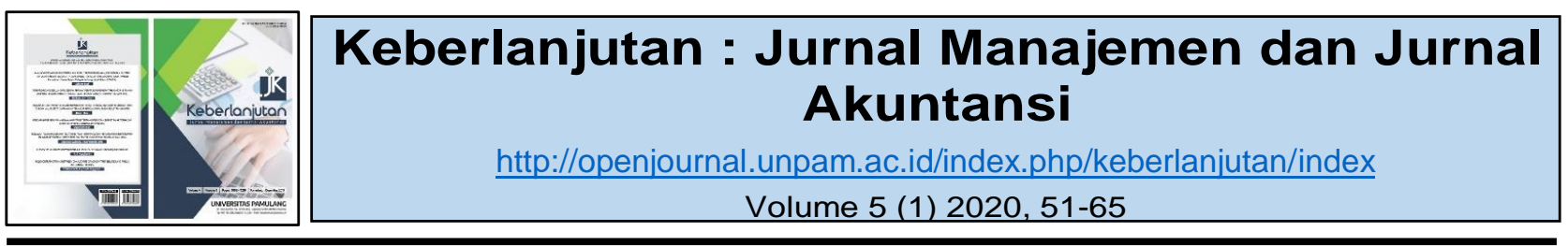

\title{
Penerapan Akuntansi Kewajiban Provisi Lingkungan Pada Perusahaan Sektor Industri Semen
}

\author{
Ronald Guntara ${ }^{1}$, Ni Luh Gede Desy Ardiani ${ }^{2}$
}

1)Politeknik Keuangan Negara STAN, Indonesia

2)Politeknik Keuangan Negara STAN, Indonesia

\section{Article Info}

Article history:

Received: 2020-06-01;

Accepted: 2020-06-18;

Published:2020-07-15;
Kata Kunci:

Implementasi,

Industri Semen Kewajiban

Penyediaan Lingkungan

\section{Abstract}

This study aims to review of the implementation of environmental provision liability accounting in cement industry sector companies by taking the objects of PT Indocement Tunggal Prakarsa Tbk, PT Semen Baturaja Tbk, and PT Semen Indonesia Tbk. The research method used in this study is to use a qualitative method with content analysis and use data on company financial statement information accessed through the Indonesia Stock Exchange website. This study concludes that the accounting treatment applied by PT Indocement Tunggal Prakarsa Tbk, PT Semen Baturaja Tbk, and PT Semen Indonesia Tbk in general is in accordance with the accounting treatment of environmental provision obligations contained in the Statement of Financial Accounting Standards (PSAK) Number 57 (2014). But in recognition only PT Semen Baturaja Tbk recognized the provision in the consolidated statement of financial position as a reclamation and post-mining provision. While $P T$ Indocement Tunggal Prakarsa Tbk and PT Semen Indonesia Tbk recognize the provision as a long-term provision.
Email Penulis

guntara26@gmail.com,desyardiani07@gmail.com
ISSN: 2614-3291 (online) http://dx.doi.org/10.32493/keberlanjutan.v5i1.y2020.p51-65 


\section{PENDAHULUAN}

Pertumbuhan industri semen di Indonesia semakin menunjukkan tren positif seiring dengan adanya pembangunan infrastruktur yang diprogramkan pemerintah. Disamping itu, kenaikan konsumsi semen nasional turut didorong oleh pembangunan yang dikerjakan masyarakat. Dari data Asosiasi Semen Indonesia (ASI) menyebutkan tentang penjualan semen di Indonesia di tahun 2017 tumbuh sekitar 7\% menjadi 66,4 juta ton dibandingkan dengan tahun sebelumnya. Jika dibandingkan dengan penjualan tahun-tahun sebelumnya, capaian ini adalah capaian tertinggi. Bahkan untuk penjualan semen ke luar negeri pada tahun 2016 meningkat tajam dari tahun sebelumnya yaitu dari 82,7\% menjadi 2,93 ton. Jumlah ini merupakan jumlah eskpor klinker 1,8 juta ton dan semen 1,13 juta ton (databoks.katadata.co.id). Bahkan dalam jangka panjang industri semen bisa naik signifikan, seiring dengan gencarnya pembangunan properti dan proyek infrastruktur.

Namun dibalik bertumbuhnya industri semen di Indonesia, terdapat tanggung jawab yang perlu dilakukan oleh perusahaan-perusahaan yang bergerak pada industri semen. Pada umumnya bahan baku pembuatan semen berupa bebatuan kapur dan tanah liat. Yang mana kedua bahan tersebut didapat di alam dengan cara penambangan. Batu kapur diperoleh dengan cara surface minner dan peledakan, lain halnya tanah liat yang didapat dengan cara pengerukan. Kemudian penyatuan dan pengolahan kedua bahan ini dilakukan di pabrik. Tanggung jawab tersebut adalah tanggung jawab lingkungan terhadap penambangan sumber daya alam bahan-bahan pembuatan semen berupa pengembalian lokasi pertambangan seperti keadaan semula (reklamasi) dan tanggung jawab pascatambang batu kapur dan tanah liat. Di dalam pelaksanaannya diperlukan perkiraan yang andal mengenai jumlah liabilitas atas tanggung jawab tersebut yang biasa disebut provisi.

Dalam PSAK Nomor 57 (2014), ketika perusahaan mempunyai kewajiban saat ini yang bersifat hukum ataupun konstruktif dan merupakan akibat kejadian masa lampau, maka kewajiban tersebut harus diselesaikan dan jumlahnya harus diperkirakan dengan andal oleh perusahaan. Jumlah provisi yang diakui merupakan hasil estimasi untuk menyelesaikan kewajiban tersebut di akhir periode pelaporan. Selain itu perlu pertimbangan ketidakpastian dan risikonya.

Dalam pelaksanaanya peraturan yang mendasari adanya kewajiban hukum ini adalah Undang-Undang (UU) No. 4 Tahun 2009 tentang Mineral dan Batubara, Peraturan Pemerintah (PP) No. 78 Tahun 2010, dan Peraturan Menteri Energi dan Sumber Daya Mineral (Permen ESDM) No. 18 Tahun 2008. Dalam Undang-Undang No. 4 Tahun 2009 tentang Mineral dan Batubara Pasal 95, dijelaskan bahwa kegiatan industri yang melakukan penambangan mineral di Indonesia diwajibkan melakukan penerapan kaidah teknik pertambangan sesuai dengan peraturan, selanjutnya industri tersebut diwajibkan melakukan pengelolaan keuangan berdasarkan dengan sistem akuntansi yang berlaku. Disamping itu, pada PP No. 78 Tahun 2010 dijelaskan mengenai reklamasi dan pascatambang, dan pada Permen ESDM No. 7 
Tahun 2014 dijelaskan tentang reklamasi dan penutupan tambang. Atas dasar inilah perusahaan sektor industri semen seharusnya melakukan tanggung jawab pertambangan yang dibuktikan dengan adanya estimasi jumlah kewajiban secara andal atas tanggung jawab tersebut pada laporan keuangannya sesuai dengan PSAK Nomor 57 (2014).

Artikel yang mengulas tentang penelitian terkait akuntansi kewajiban provisi lingkungan terhitung masih jarang. Penelitian terkait tentang akuntansi kewajiban provisi lingkungan telah dilakukan oleh Dewi (2013) yang mengulas analisa biaya lingkungan pada perusahaan non keuangan yang terdaftar pada Bursa Efek Indonesia periode 2011, 2012, dan 2013. Hasil penelitian tersebut menyimpulkan bahwa perusahaan mungkin mempunyai alokasi biaya terkait kewajiban provisi lingkungan tetapi masih dibebankan pada akun biaya tak terduga, jadi ketika dicek melalui website Bursa Efek Indonesia (www.idx.co.id) biaya tersebut tidak terlihat.

Selain itu, Sari dan Nugroho (2017) melakukan penelitian tentang persepsi akuntan pendidik terhadap konsep dasar, pengukuran, dan pengungkapan akuntansi lingkungan. Menyimpulkan bahwa biaya lingkungan dapat diukur secara moneter dan harus diungkapkan dalam laporan keuangan. Selanjutnya penelitian lainnya yang dilakukan Medina dan Firmansyah (2019) yang menganalisis penerapan akuntansi kewajiban lingkungan menyimpulkan bahwa beberapa perusahaan belum melaporkan setiap kewajiban lingkungan dalam bentuk tanggung jawab sosial-lingkungan pada laporan keuangan. Pada laporan laba rugi perusahaan, dilaporkan kegiatan tanggung jawab lingkungan atas pengeluaran perusahaan. Hal ini didasarkan karena akuntansi untuk liabilitas lingkungan terkait dengan pengakuan, pengukuran, pencatatan, pengungkapan, dan pelaporan belum diatur dalam standar akuntansi keuangan, sehingga pelaporan untuk liabilitas lingkungan masih bersifat sukarela.

Perbedaan penelitian ini dengan penelitian sebelumnya, penelitian ini bertujuan mengulas penerapan akuntansi kewajiban provisi lingkungan pada perusahaan sektor industri semen yang terjadi sebagai akibat dari kegiatan pertambangan perusahaan. Penelitian ini mengambil objek PT Indocement Tunggal Prakarsa Tbk, PT Semen Baturaja Tbk, dan PT Semen Indonesia Tbk. Alasan pemilihan objek perusahaan sektor industri semen adalah adanya kewajiban tanggung jawab lingkungan dalam menjalankan kegiatan operasi perusahaan berupa pertambangan bahan baku yang menyebabkan eksternalitas lingkungan. Selain itu, penelitian terkait akuntansi kewajiban provisi lingkungan pertambangan khususnya perusahaan sektor industri semen masih jarang dilakukan. Selanjutnya apabila dilihat dari karakteristik perusahaan, maka ketiga perusahaan tersebut dapat digolongkan sebagai perusahaan dengan akuntabilas publik. Tinjauan yang dilakukan dalam penelitian ini yang meliputi pengakuan, pengukuran, pencatatan, dan penyajian kewajiban provisi lingkungan pada perusahaan sektor industri semen didasarkan pada standar akuntansi di Indonesia (PSAK Nomor 57). 
Penelitian ini dibagi dalam lima bagian. Bagian pertama adalah pendahuluan yang mengulas mengenai fenomena penelitian, penelitian terdahulu yang telah mengulas topik penerapan akuntansi untuk kewajiban provisi lingkungan, dan tujuan penelitian atas penerapan akuntansi kewajiban provisi lingkungan. Bagian kedua adalah telaah literatur dan pengembangan hipotesis yang merupakan landasan yang digunakan sebagai dasar penelitian. Bagian ketiga yaitu metodologi penelitian yang merupakan pendekatan yang digunakan dalam menyelesaikan permasalahan penelitian. Bagian keempat yaitu hasil penelitian dan pembahasan, yang menguraikan temuan hasil penelitian sebagaimana tujuan yang hendak dicapai dalam penelitian. Bagian kelima adalah kesimpulan yang berisi tentang ringkasan hasil penelitian dan implikasi penelitian. Dari hasil uraian tesebut, penulis melakukan analisis penelitian dengan judul "Penerapan Akuntansi Kewajiban Provisi Lingkungan Pada Perusahaan Sektor Industri Semen".

\section{LANDASAN TEORITIS DAN PENGEMBANGAN HIPOTESIS Pengertian Provisi}

Dalam PSAK 57 (2014) menyebutkan provisi adalah kewajiban yang jumlah dan waktunya belum pasti, sedangkan liabilitas merupakan kewajiban perusahaan atas akibat peristiwa sebelumnya dan penyelesaiannya diestimasi memerlukan pengeluaran sumber daya perusahaan. Selaras dengan pengertian dalam PSAK 57 (2014), Weygandt et al. (2014) menyebutkan bahwa provisi ialah kewajiban yang waktu atau jumlahnya tidak bisa dipastikan (sering disebut sebagai kewajiban yang diestimasi).

Weygandt et al. (2014) menyatakan bahwa perbedaan provisi dengan liabilitas lainnya (seperti utang usaha atau wesel bayar, utang gaji, dan utang dividen) adalah bahwa provisi memiliki ketidakpastian yang lebih besar mengenai jumlah yang diperlukan dalam penyelesaian kewajiban tersebut dan waktu pelaksanaan kewajiban tersebut.

Sejalan dengan Weygandt et al. (2014), PSAK 57 (2014) menyebutkan perbedaan antara provisi dengan liabilitas lainnya (utang usaha) yaitu ketidakpastian provisi mengenai jumlah pengeluaran dan waktu dalam penyelesaian provisi tersebut pada masa yang akan datang. Dalam PSAK 57 (2014) dijelaskan juga untuk pengakuan provisi adalah hanya ketika perusahaan mempunyai kewajiban saat ini, bersifat konstruktif ataupun hukum yang merupakan akibat kejadian masa lampau, mengakibatkan pengeluaran sumber daya yang mengandung manfaat ekonomi dalam penyelesaiannya, dan perkiraan atas jumlah pengeluaran tersebut dapat dibuat. Apabila kondisi tersebut tidak tercapai, maka pengakuan provisi tidak dapat dilakukan.

Lebih lanjut PSAK 57 (2014) menyatakan kewajiban hukum terjadi karena kontrak (eksplisit maupun implisit), pelaksanaan peraturan, atau produk hukum lainnya. Sedangkan kewajiban konstruktif terjadi karena adanya persitiwa masa lalu, pernyataan yang spesifik, adanya indikasi pihak lain bahwa tanggung jawab akan diterima oleh perusahaan, dan sebagai 
akibatnya perusahaan mengindikasikan kepada pihak lain bahwa tanggung jawab tersebut akan dilakukan.

\section{Pengakuan dan Pengukuran Provisi}

Weygandt et al. (2014) menyatakan perusahaan mengakui beban dan liabilitas terkait provisi hanya jika tiga syarat terpenuhi. Pertama, perusahaan memiliki kewajiban kini (hukum atau konstruksi) sebagai akibat dari kejadian masa lampau. Kedua, adanya penyelesaian atas kewajiban yang kemungkinan besar memerlukan pengeluaran kas sumber daya yang memiliki manfaat ekonomi. Ketiga, perkiraan yang dapat diandalkan dapat dibuat untuk jumlah kewajiban. Jika ketiga kondisi tersebut tidak terpenuhi, tidak ada provisi yang diakui.

Dijelaskan dalam PSAK 57 (2014) untuk pengakuan jumlah provisi merupakan estimasi terbaik dari pengeluaran dalam penyelesaian kewajiban kini. Estimasi pengeluaran ini adalah jumlah rasional yang akan dibayar perusahaan dalam penyelesaian kewajiban saat akhir periode pelaporan atau jumlah pengalihan kewajiban kepada pihak ketiga di waktu itu. Sementara itu, Weygandt et al. (2014) jumlah yang diakui sebagai provisi adalah estimasi terbaik dari pengeluaran yang dibutuhkan dalam penyelesaian kewajiban kini. Estimasi terbaik merepresentasikan jumlah yang akan dibayarkan perusahaan dalam rangka penyelesaian kewajiban pada tanggal laporan posisi keuangan. Untuk penentuan estimasi terbaik, perusahaan harus menggunakan penilaian yang didasarkan transaksi di masa lampau atau yang serupa, diskusi dengan melibatkan para ahli, dan informasi yang terkait lainnya.

Selanjutnya, dalam PSAK 57 (2014) dijelaskan jika provisi mempunyai kondisi dan tingkatan yang berbeda, maka estimasi harus dibuat secara terpisah pada masing-masing kondisi dan tingkatan oleh perusahaan. Pengukuran provisi juga dilakukan tanpa perhitungan pajak, karena perhitungan, dampak, dan perubahannya diatur lebih lanjut dalam PSAK 46. PSAK 57 (2014) juga menyebutkan pertimbangan risiko dan ketidakpastian harus dibuat perusahaan dalam penentuan estimasi terbaik provisi. Hasilnya nilai pengukuran kewajiban akan mengalami perubahan saat penetapan risiko tersebut. Dalam kondisi ini, bukan berarti dengan adanya ketidakpastian perusahaan dapat dengan sengaja membuat dan menyajikan provisi yang lebih besar. Sehingga dalam melakukan perhitungan risiko dan menghindarkan adanya ketidakpastian, perusahaan harus berhati-hati dalam membuat estimasi provisi.

PSAK 57 (2014) menjelaskan jika dampak nilai waktu uang (time value of money) signifikan, maka jumlah provisi adalah nilai sekarang atas estimasi pengeluaran arus kas dalam penyelesaian kewajiban tersebut. Hal ini mendasari bahwa provisi yang pengeluaran uangnya timbul segera setelah periode pelaporan, akan menghasilkan jumlah yang lebih besar apabila disandingkan dengan provisi yang jumlah pengeluaran uang sama yang terjadi kemudian. Sehingga apabila pengaruhnya material, jumlah provisi tersebut harus didiskontokan. Perhitungan tingkat diskonto dilakukan sebelum pengenaan pajak terhadap cerminan penilaian pasar nilai waktu uang dan risiko berkaitan dengan provisi tersebut. Perhitungan risiko yang telah dimasukkan dalam perkiraan arus kas masa depan juga tidak 
boleh tercerminkan pada tingkatan diskonto.

Dalam PSAK 57 (2014) disebutkan peristiwa yang akan datang yang dapat berpengaruh terhadap jumlah yang dibutuhkan dalam penyelesaian suatu kewajiban harus terkandung dalam jumlah provisi apabila terdapat bukti objektif apabila persitiwa itu akan terjadi. Untuk mengukur jumlah provisi, harus memperhitungkan dampak peraturan perundang-undangan yang akan berlaku, terlebih terdapat bukti objektif jika peraturan tersebut pasti diberlakukan. Dalam kondisi sebenarnya, perusahaan sering kesulitan menentukan apakah bukti objektif yang memadai dapat dihasilkan dalam suatu kejadian.

Pada PSAK 57 (2014) disebutkan jika laporan keuangan harus mencerminkan kondisi keuangan perusahaan di akhir periodenya, bukan kondisi keuangan yang akan terjadi di masa depan. Maka dari itu perusahaan dilarang mengungkapkan provisi untuk biaya-biaya yang timbul akibat kejadian di masa depan. Dalam laporan posisi keuangan perusahaan liabilitas yang diakui hanyalah liabilitas yang sudah ada di akhir periode pelaporan.

PSAK 57 (2014) menjelaskan provisi dalam laporan keuangan memerlukan estimasi dalam penentuan jumlahnya. Karena merupakan bagian yang mendasar, penggunaan estimasi sebaiknya tidak mengurangi keandalan dari laporan keuangannya. Estimasi tersebut harus dibuat secara andal karena sifat provisi yang tidak pasti apabila dibandingkan dengan akun-akun lainnya pada laporan keuangan. Ketika estimasi andal tidak dapat dibuat, maka provisi ini tidak dapat diakui tetapi dilaporkan sebagai liabilitas kontijensi.

\section{Pengungkapan Provisi}

Dalam PSAK 57 (2014) perusahaan harus mengungkapkan setiap kewajiban provisi dengan menyebutkan nilai tercatat di awal maupun di akhir periode; penambahan jumlah provisi di periode berjalan, termasuk jumlah provisi yang mengalami kenaikan; jumlah penggunaan provisi, yaitu nilai provisi yang terjadi, digunakan, dan dibebankan di periode berjalan; jumlah yang belum terpakai yang selama periode berjalan dilakukan pembatalan; dan kenaikan pada periode berjalan, yang disebabkan karena berjalannya waktu dan dampak atas masing-masing perubahan tingkat diskonto.

Lebih lanjut dalam PSAK 57 (2014) pengungkapan setiap provisi mengharuskan karakteristik kewajiban dan estimasi pengeluaran sumber daya yang terjadi dapat diuraikan dengan singkat; asumsi utama atas ketidakpastian penggunaan sumber daya apabila dibutuhkan dalam penyediaan informasi yang memadai; dan jumlah prakiraan penggantian dengan menguraikan jumlah aset yang sudah diakui untuk prakiraan penggantian tersebut. Tetapi jika pengeluaran arus untuk penyelesaian kemungkinan kecil terjadi, maka perusahaan harus mengungkapkannya sebagai kewajiban kontijensi di akhir periode perlaporan.

\section{METODOLOGI PENELITIAN}

Dalam penelitian ini metode yang digunakan merupakan metode kualitatif yaitu menggunakan content analysis. Data yang dipakai merupakan data sekunder karena sudah 
diolah dan terdokumentasi. Penelitian dilakukan dengan melihat laporan keuangan perusahaan non-keuangan yang sudah diaudit serta terdaftar pada Bursa Efek Indonesia tahun 2017, melalui website resimi Bursa Efek Indonesia yaitu www.idx.co.id.

Berdasarkan pemilihan data yang dilakukan, perusahaan yang digunakan sebagai sampel penelitian ini merupakan tiga perusahaan sektor industri semen yaitu PT Indocement Tunggal Prakarsa Tbk, PT Semen Baturaja Tbk, dan PT Semen Indonesia Tbk dengan periode laporan keuangan tahun 2017. Dasar pemilihan objek penelitian ini yaitu perusahaan sektor industri semen yang merupakan salah satu sektor industri yang mempunyai eksternalitas lingkungan sebagai akibat dari kegiatan pertambangan. Selanjutnya, kriteria pemilihan objek dalam penelitian ini didasarkan pada tersedianya laporan keuangan tahunan periode tahun 2017 dan telah dilakukan audit.

\section{HASIL PENELITIAN DAN PEMBAHASAN}

\section{Pengakuan Provisi Lingkungan}

Dalam Undang-Undang Nomor 4 Tahun 2009 tentang Pertambangan Mineral dan Batubara, dijelaskan pengertian reklamasi dan pascatambang. Reklamasi dilakukan untuk memulihkan, menata, dan memperbaiki kualitas lingkungan dan ekosistem agar mampu berfungsi kembali sesuai peruntukannya. Kegiatan ini dilakukan sepanjang tahapan usaha pertambangan. Pascatambang adalah kegiatan yang sistematis, terencana, serta berkelanjutan untuk mengembalikan fungsi lingkungan sosial dan alam berdasarkan kondisi lokal di seluruh wilayah penambangan. Berbeda dengan reklamasi, aktivitas ini dilakukan saat berakhirnya aktivitas pertambangan baik sebagian maupun seluruhya.

Pada perusahaan sektor industri semen, provisi reklamasi atau restorasi pascatambang yang dimaksud adalah terkait tambang kapur serta tanah liat sebagai bahan baku utama pembuatan semen. Salah satu syarat diakuinya provisi berdasarkan PSAK 57 (2014) adalah perusahaan harus memiliki kewajiban masa kini yang bersifat hukum maupun konstruktif sebagai akibat dari kejadian masa lampau. Provisi reklamasi atau restorasi pascatambang merupakan kewajiban hukum perusahaan untuk memperbaiki dan mengembalikan kondisi lingkungan seperti semula yang rusak dan/atau tercemar akibat aktivitas penambangan. Kewajiban tersebut merupakan amanat dari Undang-Undang Nomor 4 Tahun 2019 dan Peraturan Pemerintah Nomor 78 Tahun 2010 mengenai Reklamasi dan Pascatambang.

Sebelum memulai operasi pertambangan, perusahaan harus terlebih dahulu memiliki ljin Usaha Pertambangan (IUP) dengan salah satu syaratnya adalah membuat rencana reklamasi dan pascatambang dalam lima tahun kedepan. Rencana tersebut masuk kedalam rencana kerja dan anggaran biaya operasi. Atas dasar hal tersebut, dapat diukur besaran provisi reklamasi dan pascatambang setiap tahunnya. Hal ini memenuhi syarat pengakuan provisi menurut PSAK 57 (2014) yaitu jumlah kewajiban tersebut dapat diestimasi dengan andal. Diatur lebih lanjut dalam Peraturan Menteri ESDM Nomor 7 Tahun 2014 tentang Pelaksanaan 
Reklamasi dan Pascatambang Pada Kegiatan Usaha Pertambangan Mineral dan Batubara, disamping membuat rencana kerja dan anggaran biaya, perusahaan berkewajiban membuat dana jaminan reklamasi dan pascatambang berdasarkan rencana reklamasi lima tahunan yang telah disampaikan kepada otoritas terkait. Dana tersebut dapat disimpan di bank pemerintah berupa asuransi, deposito berjangka, cadangan akuntansi, ataupun bank garansi. Perusahaan mengakui dana jaminan reklamasi tersebut sebagai kas dan setara kas yang dibatasi penggunaannya dan penjelasannya disajikan pada catatan atas laporan keuangan.

Kewajiban perusahaan dalam melakukan reklamasi setiap tahunnya dan di masa mendatang saat operasi tambang telah selesai tidak seketika tergantikan oleh penempatan jaminan reklamasi. Hal tersebut memungkinkan adanya arus keluar kas perusahaan. Berdasarkan uraian di atas, kewajiban reklamasi dan pascatambang dapat diakui sebagai provisi karena telah memenuhi tiga syarat pengakuan provisi sesuai PSAK 57 (2014). Penentuan besaran provisi tersebut menggunakan estimasi serta asumsi, sehingga beberapa faktor akan deipertimbangkan dalam penentuan jumlah kewajiban reklamasi maupun pascatambang tersebut.

Dalam Peraturan Menteri ESDM Nomor 7 Tahun 2014, diwajibkan bagi perusahaan untuk membayar jaminan penutupan tambang yang termasuk didalamnya biaya pembongkaran bangunan beserta sarana penunjang yang tidak lagi digunakan. Jaminan tersebut tidak membuat perusahaan terlepas dari kewajiban membongkar aset tambang di akhir masa sewa lahan. Jika ternyata akumulasi jaminan tersebut tidak cukup untuk menutupi biaya pembongkaran, perusahaan berkewajiban menambahkan jaminan tersebut. Hal itu memungkinkan adanya arus keluar sumber daya ekonomi di masa depan.

Sebagai contoh, pada Catatan Atas Laporan Keuangan Konsolidasian PT Indocement Tunggal Prakarsa Tbk, disebutkan bahwa provisi pembongkaran digunakan untuk membongkar aset tetap terminal semen dan pabrik beton siap pakai. Dilain pihak, PT Semen Indonesia Tbk pada catatan atas laporan keuangan konsolidasiannya tidak menjelaskan lebih lanjut apakah provisi pembongkaran aset tetap tersebut hanya berkaitan dengan aktivitas penambangan atau semua aset tetap yang dimiliki perusahaan. Jika estimasi memadai atas nilai wajar dapat ditentukan, kewajiban dapat diakui dalam tahun terjadinya pembongkaran tersebut. Estimasi memadai tersebut mencakup estimasi atas biaya pembongkaran aset tetap serta pengeluaran yang dibutuhkan dalam penyelesaian liabilitas atas pembongkaran atau restorasi di masa mendatang.

Ada perbedaan istilah yang digunakan oleh beberapa perusahaan besar industri semen di Indonesia dalam mengakui provisi lingkungan di laporan keuangan, disajikan dalam tabel 1. di bawah. Provisi tersebut disajikan dalam Laporan Posisi Keuangan Konsolidasian pada bagian liabilitas jangka panjang.

Berdasarkan tabel di atas, hanya PT Semen Baturaja Tbk saja yang menyajikan provisi. 
Tabel 1 Perbandingan Pengakuan Provisi Lingkungan

\begin{tabular}{|c|l|c|l|}
\hline $\begin{array}{c}\text { Nama } \\
\text { Perusahaan }\end{array}$ & $\begin{array}{c}\text { PT Semen Baturaja } \\
\text { Tbk }\end{array}$ & $\begin{array}{c}\text { PT Indocement Tunggal } \\
\text { Prakarsa Tbk }\end{array}$ & PT Semen Indonesia Tbk \\
\hline Pengakuan & $\begin{array}{c}\text { Provisi reklamasi } \\
\text { dan pascatambang }\end{array}$ & Provisi jangka panjang & Provisi jangka panjang \\
\hline
\end{tabular}

Sumber: Laporan Keuangan Konsolidasian PT Semen Baturaja Tbk, PT Indocement Tunggal Prakarsa Tbk,

dan PT Semen Indonesia Tbk Tahun 2017

lingkungan sebagai "provisi reklamasi dan pascatambang". Penggunaan istilah provisi reklamasi dan pascatambang tersebut disesuaikan dengan kewajiban perusahaan sebagaimana diatur dalam Peraturan Menteri ESDM Nomor 7 Tahun 2014. Dua perusahaan lainnya hanya menyajikan sebagai provisi jangka panjang. Perbedaan istilah provisi tersebut tidak masalah karena penyebutannya tidak diatur dalam PSAK 57 (2014). Tetapi pada catatan atas laporan keuangan kedua perusahaan tersebut, provisi jangka panjang dibedakan menjadi dua, yaitu provisi restorasi lahan bekas tambang serta provisi untuk pembongkaran aset tetap.

\section{Pengukuran Provisi Lingkungan}

Pada setiap akhir periode laporan, perusahaan akan melakukan penelaahan atas provisi restorasi tambang. Terdapat banyak faktor yang mempengaruhi kewajiban atau jumlah terutang dalam menentukan provisi tersebut sehingga dibutukan estimasi serta asumsi yang memadai serta signifikan. Berikut merupakan perbandingan faktor-faktor yang mempengaruhi besaran nilai

Tabel 2 Perbandingan Faktor - factor Yang Mempengaruhi Besaran Nilai Restorasi Tanah Tambang

\begin{tabular}{|c|c|c|}
\hline Tbk & $\begin{array}{c}\text { PT Indocement Tunggal } \\
\text { Prakarsa Tbk }\end{array}$ & sia Tbk \\
\hline $\begin{array}{l}\text { Estimasi untuk waktu dan } \\
\text { jumlah biaya untuk aktivitas } \\
\text { restorasi }\end{array}$ & $\begin{array}{l}\text { Estimasi atas biaya untuk } \\
\text { kegiatan restorasi lahan } \\
\text { bekas tambang }\end{array}$ & $\begin{array}{l}\text { Estimasi untuk waktu dan } \\
\text { jumlah biaya untuk aktivitas } \\
\text { restorasi }\end{array}$ \\
\hline Perubahan teknologi & - & Per \\
\hline Pert & Per & $\mathrm{Pe}$ \\
\hline $\begin{array}{l}\text { Peningkatan } \\
\text { dibandingkan } \\
\text { tingkat inflasi }\end{array}$ & $\begin{array}{l}\text { Kenaikan biaya karena } \\
\text { inflasi }\end{array}$ & $\begin{array}{l}\text { Peningkatan } \\
\text { dibandingkan } \\
\text { tingkat inflasi }\end{array}$ \\
\hline $\begin{array}{l}\text { Perubahan tingkat bunga } \\
\text { diskonto }\end{array}$ & $\begin{array}{l}\text { Perubahan } \\
\text { diskonto }\end{array}$ & $\begin{array}{l}\text { Perubahan tingkat bunga } \\
\text { diskonto }\end{array}$ \\
\hline
\end{tabular}

Sumber: Laporan Keuangan Konsolidasian PT Semen Baturaja Tbk, PT Indocement Tunggal Prakarsa Tbk, dan PT Semen Indonesia Tbk Tahun 2017

provisi restorasi tanah tambang di tiga perusahaan besar sektor industri semen.

Dari tabel diatas, diketahui ketiga perusahaan mempertimbangkan faktor-faktor yang pada 
umumnya sama dalam mengukur nilai provisi restorasi tanah tambang. Dalam catatan atas laporan keuangan konsolidasian, disebutkan bahwa ketidakpastian akibat faktor-faktor tersebut dapat menyebabkan jumlah pengeluaran aktual dimasa yang akan datang bisa saja berbeda dengan jumlah pencadangan kini. Jadi, jumlah provisi saat akhir periode pelaporan merupakan estimasi terbaik nilai sekarang dari biaya restorasi masa mendatang yang dibuat oleh manajemen perusahaan.

Karena merupakan kewajiban dimasa yang akan datang, pembongkaran aset tetap dihitung berdasarkan nilai masa mendatang (future value) dari estimasi biaya atau pengeluaran. Selanjutnya, kewajiban tersebut dicatat sebesar nilai present value dan akan disesuaikan dengan tingkat suku bunga atau diskonto. Dalam catatan atas laporan keuangan konsolidasian ketiga perusahaan tersebut, disebutkan bahwa untuk dapat mengetahui nilai wajar provisi pembongkaran aset tetap, asumsi dan estimasi dibuat oleh manajemen berdasarkan perkiraan biaya, tingkat diskonto dengan menggunakan tarif sebelum pajak, serta waktu pemindahan dan pembongkaran aset tetap terkait. Ketidakpastian penentuan provisi tersebut dapat menyebabkan perbedaan antara pengeluaran aktual dimasa mendatang dengan jumlah yang dicadangkan dimasa kini.

\section{Pengungkapan Provisi Lingkungan}

Telah dibahas sebelumnya bahwa provisi lingkungan dari tiga perusahaan besar industri semen di Indonesia dicatat di laporan posisi keuangan konsolidasian. Provisi tersebut diungkapkan sebagai bagian dari liabilitas jangka panjang karena jatuh tempo dalam jangka waktu yang lebih dari satu tahun. Rincian atau penjelasan mengenai saldo provisi tersebut dijelaskan pada catatan atas laporan keuangan konsolidasian. Dari ketiga perusahaan besar yang dibahas, hanya PT Semen Baturaja Tbk yang tidak merinci dan menjelaskan perubahan saldo provisi tersebut.

Meskipun telah menyetor dana jaminan reklamasi dan pascatambang, pemerintah melalui Kementerian ESDM tetap mewajibkan perusahaan yang melakukan operasi penambangan untuk melakukan restorasi lingkungan setiap tahunnya. Aktivitas restorasi tersebut tentunya menyebabkan arus keluar sumber daya (kas) dari perusahaan.

\section{Pengungkapan Provisi Lingkungan pada PT Indocement Tunggal Prakarsa Tbk}

Perusahaan telah membuat provisi jangka panjang dalam rangka menutup biaya pembongkaran aset tetap serta restorasi area bekas tambang. Provisi pembongkaran aset tetap ditujukan untuk membongkar aset tetap terminal semen serta pabrik beton siap pakai. Pada akhir 2017, saldo provisi yang sudah disisihkan sebesar Rp75.620.000.000. Pada tanggal 31 Desember 2017, saldo provisi untuk pembongkaran aset tetap sebesar Rp 56.526.000.000, sedangkan saldo provisi untuk restorasi lahan bekas tambang sebesar Rp 19.094.000.000. Dalam catatan atas laporan keuangan konsolidasian, disajikan mutasi atas provisi tersebut. Pembahasan selanjutnya akan fokus membahas mutasi pada tahun 2017. Mutasi dari provisi ini disajikan dalam tampilan 4.1 berikut ini (dalam jutaan rupiah). 
Tabel 3 Mutasi atas Provisi Lingkungan PT Indocement Tunggal Prakarsa Tbk

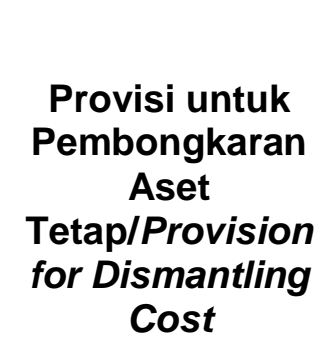

\section{Provisi untuk}

Restorasi

Lahan Bekas

Tambang

(Catatan

Total

30k)/Provision

for

Recultivation

(Note 30k)

\begin{tabular}{|c|c|c|c|}
\hline $\begin{array}{l}\text { Saldo tanggan } 31 \text { Desember } \\
2015\end{array}$ & 35,833 & 23,317 & 59,150 \\
\hline Provisi selama tahun berjalan & 4,237 & 195 & 4,432 \\
\hline Realisasi selama tahun berjalan & $(441)$ & $(2,262)$ & $(2,703)$ \\
\hline Peningkatan yang terjadi & & & \\
\hline karena berlalunya waktu & 2,969 & - & 2,969 \\
\hline $\begin{array}{l}\text { Penyesuaian atas tingkat } \\
\text { diskonto }\end{array}$ & 1,043 & - & 1,043 \\
\hline $\begin{array}{l}\text { Saldo tanggal } 31 \text { Desember } \\
2016\end{array}$ & 43,641 & 21,250 & 64,891 \\
\hline $\begin{array}{l}\text { Provisi selama tahun berjalan } \\
\text { Pembalikan selama tahun } \\
\text { berjalan }\end{array}$ & 4,278 & $\begin{array}{r}180 \\
(171)\end{array}$ & $\begin{array}{l}4,458 \\
(171)\end{array}$ \\
\hline Realisasi selama tahun berjalan & $(691)$ & $(2,165)$ & $(2,856)$ \\
\hline Peningkatan yang terjadi & & & \\
\hline karena berlalunya waktu & 3,247 & - & 3,247 \\
\hline $\begin{array}{l}\text { Penyesuaian atas tingkat } \\
\text { diskonto }\end{array}$ & 6,051 & - & 6,051 \\
\hline $\begin{array}{l}\text { Saldo tanggal } 31 \text { Desember } \\
2017\end{array}$ & 56,526 & 19,094 & 75,620 \\
\hline
\end{tabular}

Tahun 2017

Berdasarkan ketentuan pengungkapan provisi pada PSAK 57 (2014), provisi selama tahun berjalan merupakan provisi tambahan yang dibuat pada periode bersangkutan, termasuk peningkatan jumlahnya pada provisi yang ada. Pembalikan selama tahun berjalan merupakan pembatalan provisi atas jumlah yang belum digunakan selama periode bersangkutan. Realisasi selama tahun berjalan merupakan provisi yang digunakan, baik yang terjadi maupun dibebankan selama periode bersangkutan.

Terkait provisi restorasi bekas lahan tambang, realisasi muncul karena adanya kewajiban tahunan perusahaan untuk melakukan aktivitas reklamasi sesuai yang diamanatkan peraturan pemerintah. Atas reklamasi tersebut, perusahan mengakuinya sebagai beban restorasi lahan bekas tambang. Beban tersebut diungkapkan dalam laporan rekonsiliasi pajak tahun 2017 yang nilainya sebesar $\mathrm{Rp} 2.165 .000 .000$ sebagai beda temporer. Realisasi selama tahun berjalan untuk provisi pembongkaran aset tetap tidak dijelaskan lebih lanjut. Kenaikan yang terjadi karena berlalunya waktu dan penyesuaian tingkat diskonto hanya terjadi pada provisi untuk pembongkaran aset tetap untuk menyesuaikan nilai present value. Jika ditinjau 
kesesuaiannya dengan PSAK 57 (2014) par 84 mengenai pengungkapan provisi, pengungkapan provisi lingkungan pada PT Indocement Tunggal Prakarsa Tbk sudah sesuai.

\section{Pengungkapan Provisi Lingkungan pada PT Semen Indonesia Tbk}

Mengacu pada rencana reklamasi yang sebelumnya telah disampaikan kepada otoritas terkait, restorasi tanah tambang dilakukan setiap tahunnya serta diungkapkan sebagai "jumlah yang terjadi dan penyesuaiannya" dalam catatan atas laporan keuangan konsolidasian. Sedangkan, untuk pembongkaran aset tetap akan dilakukan perusahaan disaat masa sewa lahan atas aset tetap tersebut telah usai. Untuk penambahan provisi atas aset tambang dan properti lainnya yang diperoleh selama tahun berjalan dilakukan penyesuaian sebagai akibat dari pendiskontoan provisi tersebut.

Jika ditinjau kesesuaiannya dengan penerapan PSAK 57 (2014) par 84, pengungkapan provisi lingkungan pada PT Semen Indonesia Tbk relatif sesuai. Untuk pengungkapan nilai tercatat pada awal dan akhir periode telah terpenuhi. Provisi tambahan, jumlah yang digunakan, dan peningkatan yang timbul karena berlalunya waktu pada periode yang bersangkutan juga telah diungkapkan. Tidak ada jumlah provisi yang belum digunakan yang dibatalkan (pembalikan) selama periode berjalan. Namun, tidak ada informasi komparatif terkait provisi yang diungkapkan karena tidak diharuskan dalam PSAK 57 (2014).

Tabel 4. Mutasi atas Provisi Lingkungan PT Semen Indonesia Tbk

31 Desember 2017 / December 31, 2017

Jumlah

Nilai tercatat awal/

Provisi

Beginning

balance

tambahan/

Additional

provision

Restorasi

tanah

tambang

Estimasi

biaya

pembongka

ran aset

tetap

Jumlah

$\begin{array}{r}69,686,154 \\ \hline \mathbf{1 8 2 , 7 6 0 , 6 9 3} \\ \hline \hline\end{array}$

$\begin{array}{r}30,350,088 \\ \hline 33,129,821 \\ \hline \hline\end{array}$

\begin{tabular}{l}
$(3,081,915)$ \\
$\mathbf{( 7 , 0 2 9 , 5 1 6 )}$ \\
\hline
\end{tabular}

$\begin{array}{r}8,744,624 \\ \hline 15,174,576 \\ \hline \hline\end{array}$

$105,698,951$

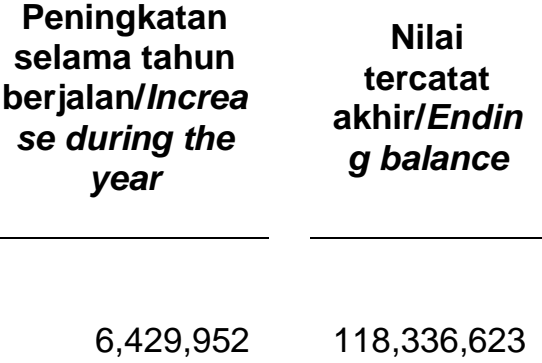

31 Desember 2016 / December 31, 2016

Jumlah yang terjadi

dan

penyesuaia

tambahan/ n/ Amount

awal/

Additional

realized and

Beginning

provision

adjustment

Restorasi

tanah

tambang

balance

Estimasi

biaya

$105,884,189$

$4,236,121$

$(3,049,387)$

$6,003,616$

$113,074,539$

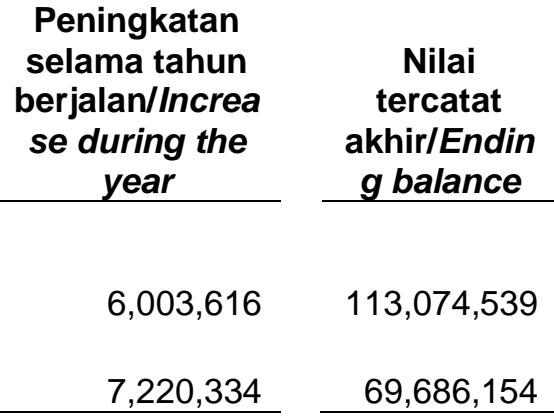


pembongka

ran aset

tetap

Jumlah

$\mathbf{1 8 5 , 5 2 6 , 8 4 0}$

$10,889,013$

$(26,879,110)$

$13,223,950$

$182,760,693$

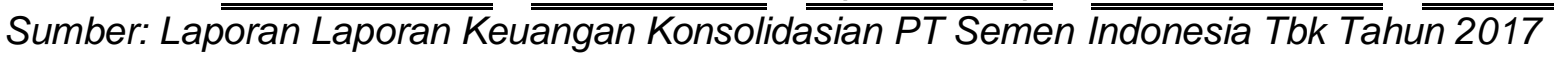

\section{Pengungkapan Provisi Lingkungan pada PT Semen Baturaja Tbk}

PT Semen Baturaja hanya mengungkapkan provisi lingkungan di laporan posisi keuangan konsolidasian pada pos liabilitas jangka panjang sebagai provisi reklamasi dan pascatambang. Pada catatan atas laporan keuangan konsolidasian tidak disajikan mutasi saldo provisi, hanya diungkapkan saldo pada akhir periode. Saldo per 31 Desember 2017 dan 2016 masing-masing sebesar Rp 6.656.237.000 dan Rp 6.094.465.000.

PSAK 57 (2104) par 84 mengharuskan perusahaan agar mengungkapkan nilai tercatat saat awal serta akhir periode, penambahan provisi yang dilakukan pada periode bersangkutan (termasuk juga penambahan jumlah provisi yang ada), jumlah terpakai, jumlah belum terpakai yang dibatalkan selama periode tersebut, serta peningkatan selama periode tersebut dalam nilai kini. Dari pengungkapan yang seharusnya dilakukan tersebut, PT Semen Baturaja hanya mengungkapkan saldo awal dan akhir tahun saja. Berdasarkan PSAK 57 (2014) par 92, perusahaan diperbolehkan untuk tidak mengungkapkan seluruh informasi terkait provisi jika hal tersebut diperkirakan dapat menyulitkan perusahaan dalam perselisihan dengan pihak lain disertai uraian umum perselisihan. Namun pada catatan atas laporan keuangannya, PT Semen Baturaja tidak mengungkapkan adanya kejadian perselisihan dengan pihak lain. Berdasarkan fakta tersebut, pengungkapan provisi lingkungan belum sesuai dengan PSAK 57 (2014).

\section{KESIMPULAN DAN SARAN}

PT Semen Baturaja Tbk, PT Indocement Tunggal Prakarsa Tbk, dan PT Semen Indonesia Tbk telah mengakui provisi lingkungan sesuai dengan PSAK 57 (2014) yang merupakan salah satu kebijakan terkait perlakuan akuntansi kewajiban provisi lingkungan yang berlaku di Indonesia. Provisi tersebut harus diakui akibat ada kewajiban hukum yang timbul dari peraturan otoritas terkait, yaitu Undang-Undang Nomor 4 Tahun 2009 tentang Mineral dan Batubara Pasal 95.

Dalam mengakui provisi lingkungan, ketiga perusahaan mencatatnya sebagai liabilitas jangka panjang. Hanya PT Semen Baturaja Tbk yang mengakui provisi tersebut pada laporan posisi keuangan konsolidasian sebagai provisi reklamasi dan pasca tambang. Dua perusahaan lainnya, PT Indocement Tunggal Prakarsa Tbk dan PT Semen Indonesia Tbk mengakuinya sebagai provisi jangka panjang, sehingga pembaca tidak langsung mengetahui bahwa provisi tersebut adalah provisi lingkungan. Pembaca harus mencari informasi mengenai provisi lingkungan pada catatan atas laporan keuangan konsolidasian.

Untuk kewajiban melakukan reklamasi tiap tahunnya, ketiga perusahaan mengukur provisi 
lingkungan menggunakan estimasi terbaik pengeluaran pada tiap akhir periode pelaporan. Dilain sisi, untuk kewajiban restorasi tanah bekas tambang dan pembongkaran aset tetap di akhir masa pemanfaatan tambang, ketiga perusahaan mengukurnya menggunakan nilai kini karena nilai waktu uang cukup material. Hal tersebut tercermin dari perusahaan yang melakukan penyesuaian atas tingkat diskonto pada akhir periode pelaporan.

Ketiga perusahaan telah memberikan penjelasan singkat tentang karakteristik kewajiban serta estimasi saat terjadinya arus keluar sumber daya disertai dengan indikasi atas ketidakpastian saat dan/atau jumlah arus keluar. Pengungkapan tersebut telah sesuai dengan PSAK 57 (2014). Selanjutnya dalam pengungkapan mutasi saldo provisi lingkungan, ketiga perusahaan tersebut telah mengungkapkannya pada catatan atas laporan keuangan konsolidasian. Pengungkapan mutasi saldo tersebut telah sesuai dengan PSAK 57 (2014) par 84. Dilain sisi, PT Semen Baturaja tidak mengungkapkan mutasi saldo provisi, hanya saldo awal dan akhir periode saja.

Untuk meningkatkan kualitas laporan keuangan dengan memberikan informasi yang handal dan terpercaya, ketiga perusahaan yang digolongkan sebagai perusahaan dengan akuntabilas publik tersebut, menerapkan kebijakan terkait perlakuan akuntansi kewajiban provisi lingkungan yang berlaku di Indonesia yaitu PSAK 57 (2014) seutuhnya. Hal tertuang dalam Undang-Undang Nomor 4 Tahun 2009 tentang Mineral dan Batubara Pasal 95 yang menjelaskan bahwa kegiatan industri yang melakukan penambangan mineral di Indonesia diwajibkan menerapkan kaidah terknik pertambangan yang baik, selanjutnya industri tersebut diwajibkan mengelola keuangan sesuai dengan sistem akuntansi Indonesia. Untuk penelitian kedepannya ketika meninjau perlakuan akuntansi kewajiban provisi perlu lebih cermat lagi dalam menggunakan dasar peraturan yang berlaku di Indonesia dikarenakan sewaktu-waktu kemungkinan dapat terjadi perubahan maupun pembaruan peraturan. 


\section{DAFTAR PUSTAKA}

Dewi, K. (2014). Analisa environmental cost pada perusahaan non-keuangan yang terdaftar di Bursa Efek Indonesia periode 2011, 2012 dan 2013. Binus Business Review, 5(2), 615-625.

Ikatan Akuntan Indonesia. (2014). Pernyataan Standar Akuntansi Keuangan 57: Provisi, Liabilitas Kontinjensi, dan Aset Kontinjensi. Jakarta: Ikatan Akuntan Indonesia.

Kementerian Energi dan Sumber Daya Mineral. (2014). Peraturan Menteri Energi dan Sumber Daya Mineral Nomor 7: Pelaksanaan Reklamasi dan Pascatambang Pada Kegiatan Usaha Pertambangan Mineral dan Batubara. Jakarta: Kementerian Energi dan Sumber Daya Mineral.

Medina S. S., \& Firmansyah A. (2019). The implementation of accounting for environmental liabilities. Jurnal Aplikasi Ekonomi, Akuntansi dan Bisnis, 1(2), 121 - 133.

Pemerintah Indonesia. (2008). Undang-Undang Republik Indonesia Nomor 4: Pertambangan dan Batubara. Jakarta: Pemerintah Indonesia.

Pemerintah Indonesia. (2010). Peraturan Pemerintah Republik Indonesia Nomor 78: Reklamasi dan Pascatambang. Jakarta: Pemerintah Indonesia.

Sari, D. R., \& Nugroho, P. I. (2017). Persepsi akuntan pendidik terhadap konsep dasar, pengukuran dan pengungkapan akuntansi lingkungan. Jurnal Akuntansi Maranatha, 9(1), 34-53.

Weygandt, J. J., Warfield, T. D., \& Kieso, D. E. (2014). Intermediate Accounting: IFRS Edition, Second Edition. New Jersey: John Willey \& Sons Inc.

https://www.industry.co.id/read/37063/pertumbuhan-industri-semen-nasional-semakin-positif diakses tanggal 13 Januari 2020.

https://semenbaturaja.co.id/proses-produksi/ diakses tanggal 13 Januari 2020

https://databoks.katadata.co.id/datapublish/2018/03/27/2017-konsumsi-semen-indonesiatumbuh-7-persen diakses tanggal 14 Januari 2020 